death. Appropriate counselling and support may then lead to relief of symptoms.

An unexplained breathing disorder was found in $65 \%$ of patients in a recent study, ${ }^{24}$ and this was reduced to $50 \%$ after arteriography. The hypoventilation syndrome $e^{25}$ may be distinguished from other anxiety states by the precipitation of typical symptoms by voluntary overbreathing and by the termination of spontaneous attacks by controlled breathing or rebreathing into a paper bag. Support and reassurance with occasional short term sedation with benzodiazepines may be required initially, but many patients will achieve complete control over their symptoms.

The status of the "hyperdynamic $\beta$ adrenergic circulatory state" ${ }^{26}$ is less certain. Panic attacks, chest pain, and palpitations may be induced by beta adrenergic agents, and beta blockers such as propranolol may reverse or suppress such attacks.

A recent revision of American psychiatric nomenclature ${ }^{27}$ includes a diagnostic category 300.01 panic disorder, whose criteria include chest pain or discomfort, choking or smothering sensations, dyspnoea, palpitations, and fear of dying. There are now several claims that this syndrome responds to treatment with tricyclic antidepressants. ${ }^{28-30}$ Mixed neurotic states, often with symptoms of both anxiety and depression, may require drug treatment to control symptoms and supportive psychotherapy. Patients with residual chest pain but no evidence of physical or emotional disorder may be treated with (among other agents) nitrates, advised to avoid coronary risk factors, and given regular positive counselling from their general practitioner.

The exceptional patient may sustain a subsequent myocardial infarction but this is likely to be recognised and dealt with promptly. More common, but harder to recognise, is the patient who denies emotional distress or stressful life events but goes on to manifest unequivocal but still unacknowledged evidence of their effects. It is this group which is most likely to tax the physician's therapeutic skills.

Professor of Psychiatry,

SYDNEY BRANDON

University of Leicester,

Leicester LE2 6LX

${ }^{1}$ Day LJ, Sowton E. Clinical features and follow-up of patients with angina and normal coronary arteries. Lancet 1976;ii:334-7.

2 Ockene IS, Shay MJ, Alpert JS, Weiner BH, Dalen JE. Unexplained chest pain in patients with normal coronary arteriograms. A follow-up study of functional status. N Engl f Med 1980;303:1249-52.

${ }^{3}$ Waxler EB, Kimbiris D, Dreifus LS. The fate of women with normal coronary arteriograms and chest pain resembling angina pectoris. Am 7 Cardiol $1971 ; 28: 25-32$.

4 Isner JM, Salem DN, Banas JS Jr, Levine HJ. Long-term clinical course of patients with normal coronary arteriography: follow-up study of 121 patients with normal or nearly normal coronary arteriograms. Am Heart f $1981 ; \mathbf{1 0 2}: 645-53$.

5asternak RC, Thibault GE, Savoia M, De Sanctis RW, Hutter AM Jr. Chest pain with angiographically insignificant coronary arterial obstruction. Clinical presentation and long-term follow-up. $\mathrm{Am} \mathcal{F} \mathrm{Med}$ $1980 ; 68: 813-7$.

${ }^{6}$ Lavey EB, Winkle RA. Continuing disability of patients with chest pain and normal coronary arteriograms. $\mathcal{F}$ Chronic Dis $1979 ; 32: 191-6$.

${ }^{7}$ Proudfit WL, Bruschke AVG, Sones FM. Clinical course of patients with normal or slightly or moderately abnormal coronary arteriograms: 10-year follow-up of 521 patients. Circulation 1980;62:712-17.

${ }^{8} \mathrm{Khan} \mathrm{AH}$, Haywood LJ. Myocardial infarction in nine patients with radiologically patent coronary arteries. $N$ Engl 7 Med 1974;291:427-31.

${ }^{9}$ Arnett EN, Roberts WC. Acute myocardial infarction and angiographically normal coronary arteries: an unproven combination. Circulation 1976; 53:395-400.

${ }^{10} \mathrm{Kemp}$ HG Jr, Vokonas PS, Cohn PF, Gorlin R. The anginal syndrome associated with normal coronary arteriograms: report of a six year experience. Am f Med 1973;54:735-42.

${ }^{11}$ Marchandise B, Bourassa MG, Chaitman BR, Lesperance J. Angiographic evaluation of the natural history of normal coronary arteries and mild coronary atherosclerosis. Am $\mathcal{f}$ Cardiol 1978;41:216-20.
12 Proudfit WL, Shirey EK, Sones FM Jr. Selective cine coronary arteriography: correlation with clinical findings in 1,000 patients. Circulation $1966 ; 33: 901-10$

${ }^{13}$ Faxon DP, McCabe CH, Kreigel DE, Ryan TJ. Therapeutic and economic value of a normal coronary angiogram. Am f Med 1982;73: $500-5$.

${ }^{14}$ Fox KM. Myocardial infarction and the normal coronary arteriogram. (Editorial.) Br Med f 1983;287:446-7.

${ }^{15}$ Parkes CM. Bereavement. Studies of grief in adult life. London: Tavistock Publications, 1972.

${ }_{16}$ Parkes CM, Benjamin B, Fitzgerald RG. Broken heart: a statistical study of increased mortality among widowers. Br Med f 1969;i:740-3.

17 Bennet G. Bristol floods 1968. Controlled survey of effects on health of a local community disaster. Br Med f 1970;iii:454-8.

${ }^{18}$ Adler A. Two different types of post-traumatic neurosis. Am $\mathcal{F}$ Psychiatry

$1945 ; 102: 237-40$.
${ }^{19}$ Grinker RR, Spiegel JP. War neuroses. Philadelphia: The Blakiston Co, $\frac{\overline{\bar{S}}}{\bar{D}}$ 1945

${ }^{20}$ Wood P. Da Costas syndrome (or effort syndrome). Br Med f 1941 ; i. ڤ

DeBacker G, Kornitzer M, Kittel F, Dramaix M. Behavior, stress, and $\vec{\circ}$ psychosocial traits as risk factors. Prev Med 1983;12:32-6.

${ }^{22}$ Groen JJ. Psychosomatic aspects of ischaemic (coronary) heart disease. $\overrightarrow{\vec{\omega}}$ In: Hill $\mathrm{O}$, ed. Modern trends in psychosomatic medicine 3. London: Butterworths, 1976:288-329.

${ }^{23}$ Todd JW. Query cardiac pain. Lancet 1983;ii:330-2.

${ }^{21}$ Bass C, Cawley RH, Wade C, et al. Unexplained breathlessness and psychiatric morbidity in patients with normal and abnormal coronary arteries. Lancet 1983; :605-9.

${ }^{25}$ Lum LC. Hyperventilation and anxiety states. $\mathcal{F} R$ Soc Med $1981 ; 74: 1-4$.

${ }^{26}$ Frohlich ED, Tarazi RC, Dustan HP. Hyperdynamic $\beta$-adrenergic circulatory state. Increased $\beta$-receptor responsiveness. Arch Intern Med. $1969 ; \mathbf{1 2 3}: 1-7$

2 American Psychiatric Association. Diagnostic and statistical manual of mental disorders. 3rd ed. Washington DC: American Psychiatrico Association, 1980.

${ }^{28}$ Zitrin CM, Klein DF, Woerner MG. Behavior therapy, supportive $\vec{\oplus}$ psychotherapy, imipramine, and phobias. Arch Gen Psychiatry 1978; 35:307-16.

${ }^{29}$ Sheehan DV, Ballenger J, Jacobsen G. Treatment of endogenous anxiety with phobic, hysterical, and hypochondriacal symptoms. Arch Genz Psychiatry 1980;37:51-9.

${ }^{30}$ Klein DF. Anxiety reconceptualized: early experience with imipramine $\frac{\mathbb{D}}{-}$ and anxiety. Compr Psychiatry 1980;21:411-27.

\section{A better deal for overseas doctors}

Some of the most distinguished members of our profession and many others who provide indispensable service first came to Britain as "overseas doctors". The problems facing these doctors seem likely to become worse in the immediate future.

The last few years have seen competition for good senior: house officer posts increase as British medical schools have increased their output of doctors and vocational training pro-o grammes for general practice have burgeoned. Too often, foreign graduates find that they are unable to get good jobs in 궁 the specialty which they wish to study and they fail the examin- $N$ ations which they had hoped would testify on their return home? to their successful training. They then stay on in a series of unsatisfactory posts, sometimes as locums, until, in their late 0 30 s or carly 40 s, married and with a family, they realise theyc have no prospects here or in their own country. With an understandable sense of grievance they are apt to blame the system for lack of training opportunities.

Certainly more could be done to give career guidance early? on. There are still some poor junior hospital posts despite efforts by hospital staff and postgraduate authorities to provide integrated senior house officer rotation schemes and the recent requirement by the General Medical Council that only postso approved for training by the royal colleges and faculties can be filled by doctors with limited registration. The Professional ando Linguistic Assessments Board test does ensure minimum 
standards of knowledge and skill for overseas doctors, but if numbers exceed the places available for training some people will fail to ascend the ladder or even secure a first foothold.

Doctors from India and Pakistan, Sri Lanka, Malaysia, and Iraq account for three quarters of those seeking training in Britain. Many arrive under their own impetus, with little understanding of the requirements for training and without having obtained the support of their teachers. Few consult bodies such as the National Advice Centre which can indicate what opportunities are available; few seem to have given serious attention to planning their return to a career at home.

Any scheme for improving the training of overseas doctors must take account of the realities of medical manpower in Britain and the demand for proper training of our own graduates. With few exceptions doctors with limited registration are debarred by law from training for general practice, so the hospital service must provide their openings. Present anxieties among junior hospital staff are such that the Overseas Doctors' Association has proposed closing down the Professional and Linguistic Assessments Board test for a year or two to impose a moratorium on new entrants. Given the British tradition of postgraduate medical education and our continued dependence on overseas doctors for junior hospital staff this proposal is probably impracticable. In England and Wales last year $49 \%$ of registrars and $46 \%$ of senior house officers were born outside Britain, and $17 \%$ and $20 \%$ respectively had limited registration. The number of British medical students should be properly adjusted to the number of career posts, but, even with the recession and its inhibitory effect on the proper development of the National Health Service, there will still be an excess of junior posts with training facilities which could be used by overseas doctors.

Last year one of us (DIW) put forward a plan for a National Overseas Doctors' Sponsorship Organisation to try to improve the prospects of doctors from abroad. Its object is to match overseas entrants to opportunities by providing a parallel training scheme which would not compete with the needs of our own graduates. At the same time the present staffing structure would be preserved without overloading the popular specialties with aspiring consultants. The scheme is at present being considered by the various bodies concerned with manpower and postgraduate education.

In essence, a doctor seeking training in Britain would be supported by his or her own medical authorities and given an indication of the likelihood of employment on return. Detailed applications would be sent in advance to a clearing house in Britain and if acceptable would be passed to an adviser in the chosen specialty, who would indicate suitable posts. The doctor would then be accepted for sponsorship and, after the usual formalities relating to registration, would apply in competition for jobs within the quota allocated to overseas doctors. Once appointed, he or she would perform the same duties as other senior house officers and registrars for the same remuneration but would not be regarded as training for a career in Britain. Supervision and monitoring of progress would be the responsibility of the consultant, clinical tutor, and regional dean, with the help of college and faculty advisers. The scheme could be administered by a relatively small central secretariat, possibly developed from the present National Advice Centre, and the expense would not be great.

The scheme would do nothing to prevent individual doctors making their own arrangements; many small scale sponsorship schemes have been in existence for years and have proved their worth. But a wider organisation is urgently required to correct the imbalance between junior staff and consultant vacancies and to fill the surplus of training posts. Consultants and health authorities must accept responsibility for training junior staff, whether from home or abroad, and junior staff must realise that all disciplines in all regions must be properly staffed. If more British doctors continue to enter the popular specialties than can be accommodated as consultants the present chaos will continue and overseas doctors will be forced into taking posts which are not of their choosing. Allocating the excess posts to sponsored overseas trainees would be much more sensible than reducing numbers, as the Short committee recommended. Once agreement is reached, such a scheme could be set up quickly; overseas doctors would benefit from individual satisfaction, greatly to the advantage of Britain's reputation abroad, and a solution to the manpower and training problems that have dogged British graduates for 30 years would at last be in sight.

DAvid INNES Williams Director

Alex Paton

Postgraduate dean, North East Thames region British Postgraduate Medical Federation,

London WCl 3EJ

\section{Microbiological quality assessment and the clinician}

Over the past decade laboratory doctors and other medical scientists have become more and more acclimatised to external investigations of their activities-usually undertaken to study the cost effectiveness of their work. Nevertheless, they may resent this procedure acutely if the investigating teams consist of lay people totally unfamiliar with the subject. Only slightly more tolerable is the inspection of departments by scientific review teams, who may in fact offer, even if unsolicited, good scientific advice. The medical profession is especially sensitive to any suggestion, even the most tactful, that its work is not of the highest standard. It is against this difficult background that national external quality assessment schemes have been introduced over the past few years into most branches of pathology. This article, however, covers solely the development and benefits that the scheme has brought for microbiology. Microbiologists, like their colleagues in other laboratory specialties, are really the "middle" men in medicine, passing their results (with or without advice) through to clinicians, who then apply this information to the management of their patients. Clinicians may be classified into two varieties - those who believe the laboratory report and those who do not. It is the object of the national external quality assessment schemes and this article to assure sceptical clinicians that there is a scheme aimed at maintaining a high standard of laboratory work.

Britain has 442 laboratories practising microbiology, and all National Health Service laboratories concerned with diagnostic work submit themselves to quality assessment. This in itself is a remarkable achievement because the assessment scheme is entirely voluntary-but we emphasise to our participants that the objects of the scheme are purely educational and that the results they achieve are entirely confidential. 